\title{
Model Sistem Pencatatan Digital pada Peternakan Sapi Nasional melalui Implementasi Teknologi Agromilenial sebagai Solusi Jitu Tercapainya Swasembada Sapi di Indonesia
}

\section{(Digital Recording System Models on National Cattle Farming using Agromillenial Technology for Accurate Solution of Indonesian Beef Cattle Selfsufficient)}

\author{
Ihwan $\mathrm{S}^{1}$, Usman $\mathrm{A}^{2}$, Putra BW

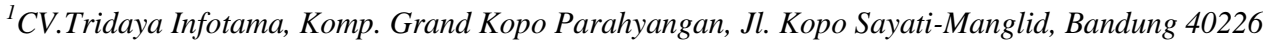 \\ ${ }^{2}$ PT. Citra Alam Semesta, Gd. Ranuza, lt.5, Jl Timor no. 10, Gondangdia, Jakarta Pusat \\ ${ }^{3}$ Fakultas Peternakan, Institut Pertanian Bogor, Jl Agatis, Kampus IPB Darmaga Bogor-16680 \\ Mahasiswa Program Doktoral, Fakultas Peternakan, Universitas Gadjah Mada, Yogyakarta 55281 \\ bramada.w.putra@gmail.com
}

\begin{abstract}
The main problem in the livestock sector in Indonesia which is very crucial is the absence of a system for recording raw farms that can be a valid reference to determine population development, productivity, reproductive status, distribution, level of livestock availability and mapping of potential and national livestock problems. Common problems that occur in manual data collection, including data input errors due to errors in reading and recording, also the occurrence of multiple data due to the absence of a Unique-ID that is the identity of each cow. A simple way can be done to anticipate this, by utilizing microchips in the form of RFID tags that are attached to each cow, in addition to avoiding human error both in counting and recording, also eliminating the possibility of double data, because each RFID Tag has a Unique-ID as the identity of each cow. The model of digital recording using RFID can be implemented on national farms with a variety of typological scenarios both nationally and regionally in macro farms, livestock areas and people's farms. A simple scenario that is planned to be implemented in both the BPTU-HPT, the Central Animal Husbandry Center, and other commercial livestock breeders is the recording of initial data, updates on incident and action data, and recording of livestock movements. Output information that can be presented using software developed is initial data, inventory activities, fattening activities, breeding activities, inventory reports, reporting fattening, breeding reports.
\end{abstract}

Key words: Digital recording, RFID, national livestock of Indonesia

\begin{abstract}
ABSTRAK
Permasalahan utama bidang peternakan di Indonsia yang sangat krusial adalah belum adanya sistem pencatatan peternakan baku yang dapat menjadi acuan valid untuk mengetahui perkembangan populasi, produktivitas, status reproduksi, distribusi, tingkat ketersediaan ternak maupun pemetaan potensi dan permasalahan peternakan nasional. Masalah umum yang terjadi pada pendataan secara manual, antara lain kesalahan input data akibat kesalahan pembacaan maupun pencatatan, juga terjadinya data ganda akibat tidak adanya unique-ID yang menjadi identitas setiap sapi. Cara sederhana dapat dilakukan untuk mengantisipasi hal tersebut, dengan memanfaatkan microchip dalam bentuk RFID Tag yang melekat pada setiap sapi, selain menghindari terjadinya human error baik pada saat penghitungan maupun pencatatan, juga meniadakan kemungkinan terjadinya data ganda, karena setiap RFID tag memiliki unique-ID sebagai identitas setiap sapi. Penelitian ini dilakukan dari tahun 2012
\end{abstract}


hingga tahun 2016. Model pencatatan digital menggunakan RFID dapat diimplementasikan pada peternakan nasional dengan berbagai skenario tipologi baik secara makro nasional maupun regional pada perusahaan peternakan, kawasan peternakan maupun peternakan rakyat. Skenario sederhana yang direncanakan untuk diimplementasikan baik di BPTU-HPT, sentra peternakan rakyat, maupun peternakan komersil lainnya, meliputi pencatatan data awal, update data kejadian dan tindakan, serta pencatatan perpindahan ternak. Keluaran informasi yang dapat disajikan dengan menggunakan software yang dikembangkan adalah data awal, aktivitas persediaan, aktivitas fattening, aktivitas breeding, laporan persediaan, laporan fattening, laporan breeding.

Kata kunci: Pencatatan digital, RFID, peternakan nasional

\section{PENDAHULUAN}

Peternakan merupakan salah satu bidang usaha yang sangat potensial untuk dikembangkan di Indonesia dan menjadi suatu industri besar serta berkontribusi pada Produk Domestik Bruto. Berbagai keunggulan yang dimiliki Indonesia untuk mengembangkan sektor peternakan antara lain: daya dukung lahan, keragaman plasma nutfah, iklim dan geografis, serta sumberdaya manusia. Lahan di Indonesia merupakan lahan subur yang sangat bagus untuk pengembangan peternakan, baik dalam bentuk usaha tunggal maupun terintegrasi dengan bidang lain seperti pertanian, perkebunan dan kehutanan. Kebutuhan lahan untuk pembiakan ternak di Indonesia jauh lebih efisien dibandingkan dengan Australia yang saat ini justru menjadi sumber sapi untuk pemenuhan kebutuhan daging di Indonesia. Kapasitas tampung rata-rata per hektar lahan di Indonesia mampu untuk memelihara 6 satuan ternak, sedangkan di Australia, untuk pemeliharaan 1 satuan ternak membutuhkan lahan hingga 10 ha. Keragaman plasma nutfah Indonesia juga memiliki potensi besar yang belum termanfaatkan. Indonesia memiliki sapi Bali, sapi Madura, sapi Peranakan Ongole dan berbagai spesies ternak lokal yang memiliki karakteristik unggul untuk dikembangkan sebagai penghasil daging premium. Iklim yang sangat mendukung untuk pertanian menjadikan kekuatan berikutnya dalam pengembangan peternakan. Curah hujan dan intensitas pencahayaan matahari yang tinggi merupakan syarat utama tanaman dapat tumbuh dengan baik, ditambah dengan sebagian besar tanah di Indonesia merupakan tanah vulkanis yang subur. Dengan kondisi ini maka kebutuhan pakan ternak dapat terpenuhi baik melalui pengolahan limbah pertanian dan perkebunan, ataupun melalui kultivasi hijauan pakan ternak berkualitas. Posisi geografis Indonesia yang strategis untuk pasar pangan dunia serta jumlah penduduk Indonesia yang cukup besar merupakan potensi pasar yang tidak pernah tergarap dalam bidang peternakan.

Upaya pengembangan bidang peternakan telah dilakukan dalam kurun waktu yang cukup lama, namun belum ada perkembangan yang signifikan dalam kemandirian industri peternakan di Indonesia terutama sapi potong. Mulai dari pengadaan bibit, pendampingan, persilangan hingga optimalisasi tingkat kebuntingan telah dilakukan, tetapi belum menunjukkan capaian besar untuk perbaikan peternakan sapi potong di Indonesia. Salah satu permasalahan utama bidang peternakan terutama ternak ruminansia besar (sapi potong dan kerbau) yang sangat krusial adalah Indonesia belum memiliki sistem pencatatan peternakan baku yang dapat menjadi acuan valid untuk mengetahui perkembangan populasi, produktivitas, status reproduksi, distribusi, tingkat ketersediaan ternak maupun pemetaan potensi dan permasalahan peternakan nasional. Tanpa adanya data yang valid, maka strategi yang diambil pun akan memiliki tingkat keberhasilan yang rendah. Dengan adanya sistem pencatatan yang baik, maka Indonesia berpotensi untuk 
dapat mandiri dalam penyediaan daging nasional yang saat ini masih disuplai dari luar sebanyak 1,85 juta ekor sapi setiap tahunnya atau setara dengan 29,5 Trilyun rupiah per tahun.

Berdasarkan kondisi tersebut, model sistem pencatatan digital pada peternakan nasional perlu dilakukan sebagai solusi yang menjawab tentang kondisi pencatatan ternak nasional yang belum terkelola dengan baik. Model dilakukan untuk mengimplementasikan sistem pencatatan elektronik menggunakan RFID dalam sistem peternakan ternak ruminansia besar di Indonesia.

Pemanfaatan teknologi informasi salah satunya diwujudkan dalam software (aplikasi) komputer Sistem Identifikasi Ternak Nasional yang mencatat setiap aktifitas dilapangan mulai dari kedatangan sapi dengan identitas menggunakan RFID, pemberian pakan dan perawatan selama masa pelihara, aktifitas reproduksi pada pembiakan serta produksi pada pembesaran dan penggemukan, perpindahan dan penjualan sapi sampai dengan pemotongan. Seluruh aktifitas tersebut merupakan satu kesatuan sehingga output informasi yang dihasilkan dapat menggambarkan kondisi di lapangan yang tidak hanya bermanfaat bagi internal peternak dalam suatu kawasan peternakan, namun pada tahap lanjutan ketika data dari setiap kawasan peternakan dapat saling bersinergi membentuk database Sistem Identifikasi Ternak Nasional maka informasi yang dihasilkan akan sangat bermanfaat bagi para pemangku kepentingan - baik pemerintah maupun swasta terutama dalam kaitannya dengan evaluasi untuk pengembangan peternakan berkelanjutan.

\section{MATERI DAN METODE}

\section{Waktu dan tempat penelitian}

Penelitian ini merupakan rangkaian riset mandiri yang dilakukan dari tahun 2012 hingga tahun 2016 dengan melakukan ujicoba pada beberapa perusahaan penggemukan dan perusahaan pembibitan sapi potong di Indonesia.

\section{Daftar kebutuhan perangkat}

\section{Di site/farm}

$\checkmark \quad$ PC : sebagai Database Server (MariaDB)

$\checkmark \quad$ PC / Laptop : untuk kebutuhan di penimbangan, terhubung ke timbangan melalui serial RS-232, dan terhubung dengan RFID Reader melalui serial RS-232 atau Bluetooth

$\checkmark \quad$ PC / Laptop : sebagai pc client (Administrasi Livestock dan Feedmill)

$\checkmark$ Jaringan Komputer : antara PC / Laptop di timbangan dengan PC di Kantor Farm

$\checkmark \quad$ Router dengan koneksi internet + VPN : untuk sinkronisasi data antara Farm - Head Office

$\checkmark \quad$ Kabel USB to Serial : untuk komunikasi antara timbangan dengan PC / Laptop (optional)

$\checkmark \quad$ RFID Reader dan USB Bluetooth Dongle (apabila pada PC tidak terdapat bluetooth)

$\checkmark \quad$ RFID Ear Tag / RFID Glass Tag : untuk identitas sapi 


\section{Di head office}

$\checkmark \quad$ PC : sebagai Database Server (MariaDB) / Mirror dengan Farm

$\checkmark \quad$ PC / Laptop : sebagai pc client (Administrasi Livestock dan Feedmill)

$\checkmark \quad$ Jaringan Komputer : antara Database Server dengan PC Client

Router dengan koneksi internet + VPN : untuk sinkronisasi data antara Farm - Head Office

\section{Implementasi}

Software dapat berjalan secara multi user, baik dalam jaringan (wireless) local area network di farm, maupun dalam kerangka interkoneksi antara farm dengan kantor diluar farm (misal: kantor pusat), sehingga setelah komputer dan infrastruktur jaringan dinyatakan siap, selanjutnya dilakukan sosialisasi sekaligus implementasi yang melibatkan user dan pihak berkepentingan lainnya (Manajemen). Kesiapan perangkat pendukung (Timbangan Sapi dan RFID Reader) merupakan syarat yang juga harus dipenuhi untuk otomatisasi pencatatan berat dan identitas sapi. Untuk menjamin software dapat dijalankan dengan baik dan benar, dilakukan pelatihan pelaksanaan implementasi dilakukan secara bertahap, dimana umumnya memerlukan waktu 3 (tiga) sampai 5 (lima) kali pertemuan dalam bentuk pelatihan dan simulasi yang dilakukan langsung di site, dengan durasi setiap pertemuan antara 3 (tiga) sampai 5 (lima) hari kerja. Dari pengalaman kami, pelatihan dan simulasi lebih efektif dilakukan dengan cara :

$>\quad$ Peternak menyiapkan PIC 2 (dua) atau 3 (tiga) orang untuk dilatih mengenai software secara keseluruhan, mulai dari installasi, operasional penggunaan, dan trouble shooting.

> PIC ini kemudian akan menjadi Administrator System, yang bertanggung jawab atas berjalannya sistem, termasuk melakukan trouble shooting kecil.

$>$ Administrator Sistem akan men-trainning user (sesuai dengan hak akses yang diberikan) dengan penampingan dari kami. Hal ini sekaligus untuk memastikan bahwa Administrator Sistem menguasai software secara utuh dan benar.

Dalam kerangka interkoneksi antara farm dengan kantor diluar farm, pola yang digunakan adalah sinkronisasi / replikasi, sehingga database pada setiap lokasi akan menjadi identic. Hal ini dilakukan karena selain untuk mempercepat akses pada masingmasing lokasi, pola ini juga bermanfaat sebagai backup database, dimana ketika terjadi bencana pada salahsatu lokasi maka mirror database pada lokasi lain dapat digunakan untuk pemulihan sistem secara cepat.

Piranti ini juga dilengkapi cloud database server yang dapat difungsikan baik untuk kebutuhan akses dari luar kantor (kapanpun dan dari manapun) maupun sebagai tambahan backup.

\section{HASIL DAN PEMBAHASAN}

\section{Gambaran umum sistem}

Secara umum software ini terdiri dari beberapa modul, yaitu:

- Persediaan, dengan lingkup mulai dari permintaan pengaraan barang (terdiri dari: Bahan Baku Pakan, Feed Additive, Hijauan, Konsentrat, Vitamin dan Obat, dan Barang Umum), pemesanan dan penerimaan barang, pengeluaran barang dan 
produksi konsentrat serta distribusinya termasuk penjualan dan retur penjualan serta pengelolaan hutang dan piutang.

- Aktifitas Fattening, dengan lingkup mulai dari penerimaan sapi baik lokal maupun import, operasional pemeliharaan yang meliputi pemberian pakan dan pelaksanaan treatment (perawatan/pengobatan) serta mutasi baik individu maupun koloni, pelaksanaan timbang ulang untuk mengukur produktifitas (ADG), dan penjualan dengan output slip data timbang, surat jalan, dan faktur penjualan.

- Aktifitas Breeding dengan lingkup pemeliharaan sebagaimana pada modul Fattening, dengan penambahan fokua pada operasional reproduksi baik melalui Inseminasi Buatan (IB) maupun Kawin Alam, yang meliputi Pemeriksaan Organ Reproduksi, Pelaksanaan IB, Pemeriksaan Kebuntingan dan Kelahiran, Identifikasi Pedet dan Penyapihan (Weaning).

- Keuangan sederhana dengan lingkup Pencatatan Perkiraan (Chart Of Account / COA), Pengelolaan Kas dan Bank, serta Jurnal Umum dengan output Neraca Percobaan (Trial Ballance), Laporan Laba / Rugi (Profit Loss), dan Arus Kas (Cash Flow).

Dengan tujuan meningkatkan efisiensi dan produktifitas melalui percepatan kinerja dan penyajian informasi secara cepat dan akurat, salah satu kekuatan dari software ini adalah otomatisasi pencatatan berat dari timbangan dan pencatatan identitas ternak menggunakan RFID Reader. Hal ini penting untuk menghindari terjadinya human error baik berupa kesalahan penyebutan, penulisan, maupun entry data. Selain itu dengan adanya historycal data baik pemeliharaan maupun reproduksi diharapkan dapat membantu manajemen baik dalam melakukan analisa dan evaluasi maupun pengambilan keputusan. Skenario implementasi sistem pencatatan peternakan digital pada tipologi makro Sistem Identifikasi Ternak Nasional disajikan dalam Gambar 1.

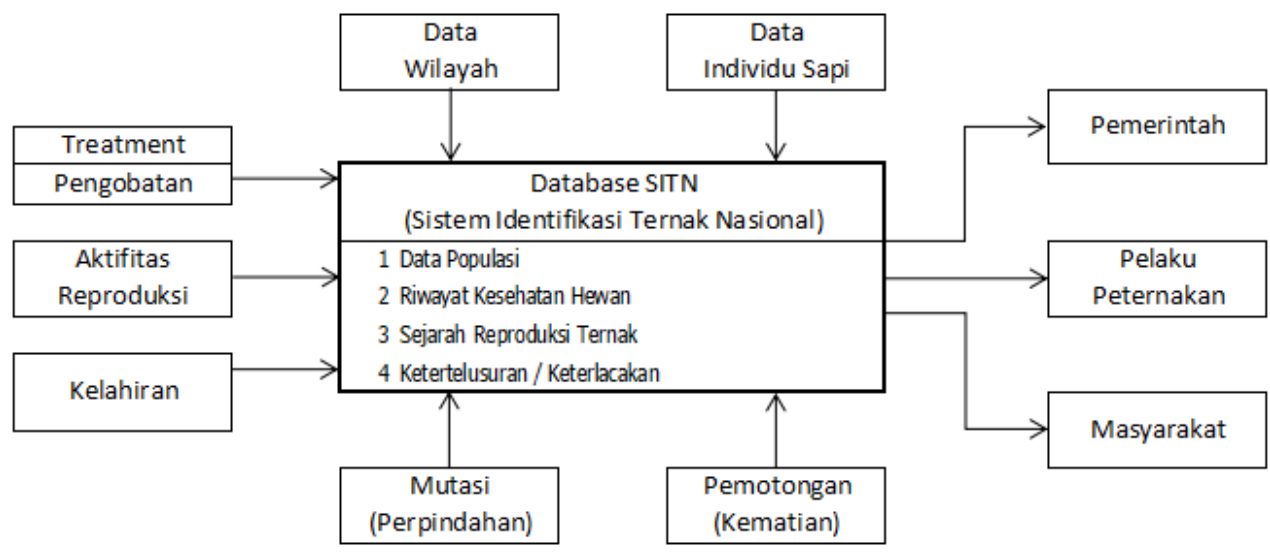

Gambar 1.Skenario implementasi sistem pencatatan peternakan digital pada tipologi makro Sistem Identifikasi Ternak Nasional

Skenario pada tipologi makro nasional memungkinkan untuk mendapatkan data holistik yang meliputi :

- Data individu ternak yang akan memberikan akurasi jumlah populasi ternak nasional 
- Data kawasan peternakan yang dapat memberikan informasi terkait kondisi, aktivitas, perkembangan, kendala pada masing-masing kawasan serta dapat dilakukan interkoneksi antar kawasan.

- Data jalur sistem usaha peternakan mulai dari unit pembibitan, pembesaran, penggemukan hingga rumah pemotongan ternak yang sangat diperlukan dalam melakukan kontrol dan pengambilan kebijakan.

- Data pendukung utama seperti logisttik, distribusi, kasus penyakit, status reproduksi, permintaan ternak dan hasil ternak.

- Akumulasi data terpusat akan sangat memungkinkan bagi pemerintah daerah kabupaten/kota, pemerintah daerah provinsi dan pemerintah pusat untuk menerima data terakumulasi mulai dari individu ternak terakumulasi pada kawasan ternak/perusahaan peternakan, yang diteruskan dalam akumulasi bertingkat mulai dari pemerintah kabupaten/kota, provinsi hingga pusat dengan data yang lebih akurat, dinamis dan nyata serta dapat dipertanggungjawabkan. Data ini yang diharapkan mampu menjadi dasar dalam pengambilan keputusan dan kebijakan nasional dalam bidang peternakan.

Penerapan software peternakan dilapangan dapat dilakukan pada perusahaan peternakan, kawasan peternakan ataupun Sentra Peternakan Rakyat untuk membantu operasional industri peternakan baik dalam unit pembibitan maupun penggemukan disajikan dalam Gambar 2.

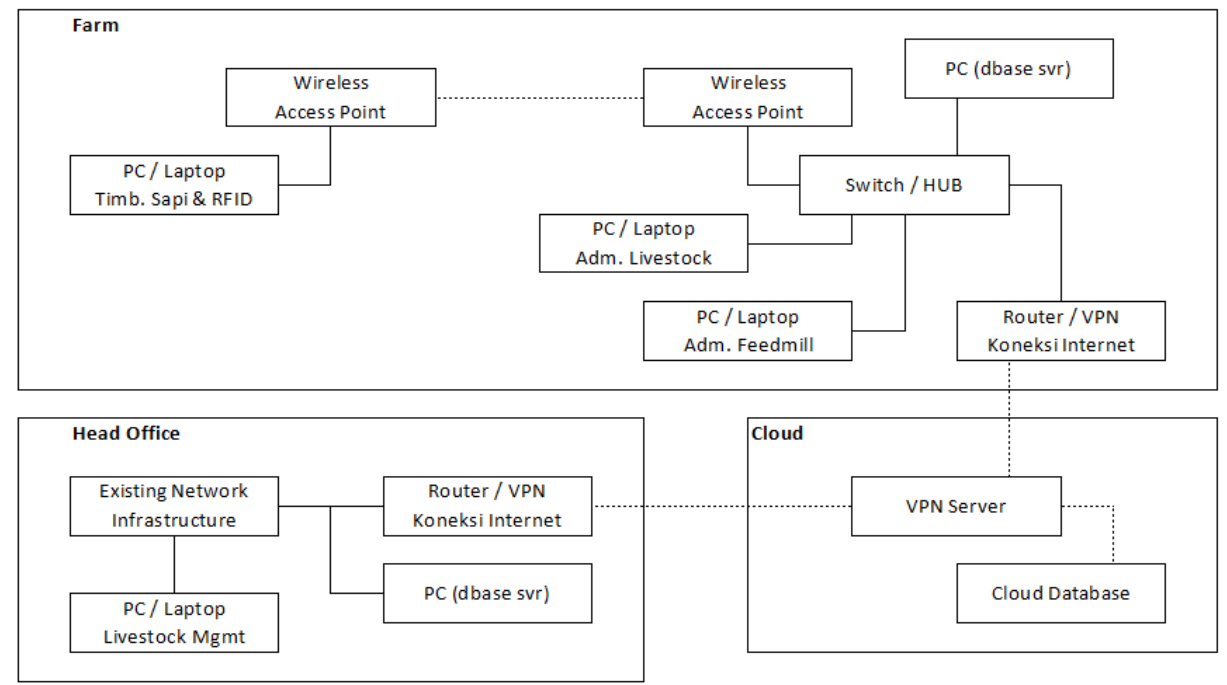

Gambar 2. Skenario implementasi sistem pencatatan peternakan digital pada tipologi perusahaan peternakan ataupun kawasan peternakan 


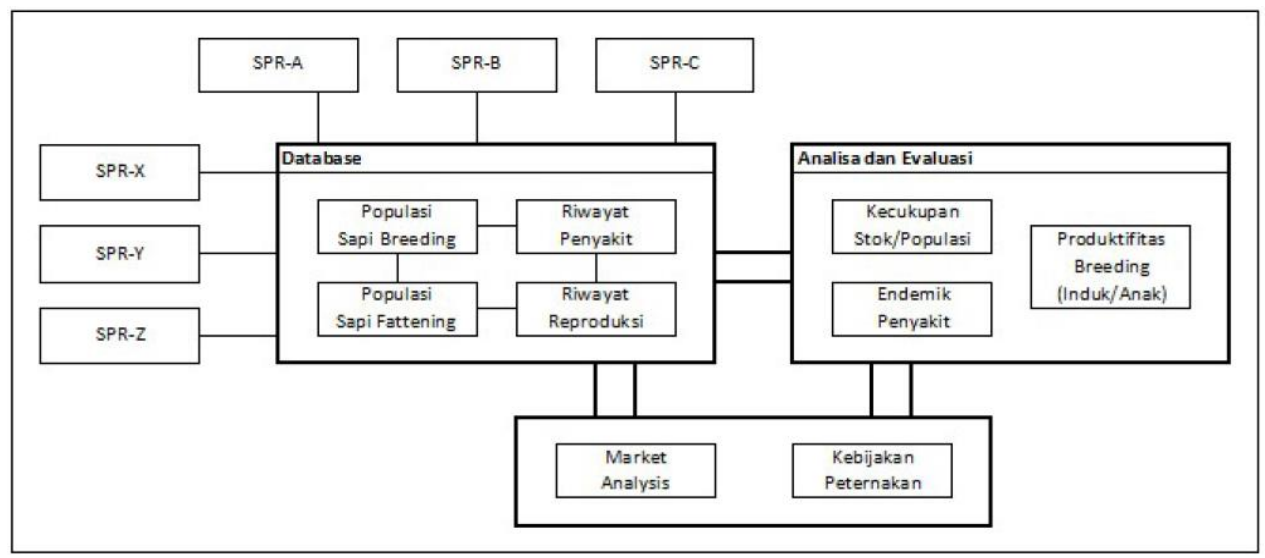

Gambar 3. Skenario implementasi sistem pencatatan peternakan digital pada tipologi interkoneksi Sentra Peternakan Rakyat

Dengan skenario tersebut dimana beberapa kekuatan sistem terletak pada otomatisasi pencatatan identitas (menggunakan RFID Scanner) dan otomatisasi pencatatan berat sapi dari Timbangan, serta pemanfaatan jaringan baik internal maupun melalui internet, selain terjadi sinergi antar setiap bagian di farm, juga monitoring dan evaluasi setiap aktifitas di farm dapat dilakukan dari Head Office atau dari tempat lainnya, kapanpun dan dari manapun.

Dalam kaitannya dengan Sistem Pencatatan Digital Pada Peternakan untuk menghasilkan Database Sistem Identifikasi Ternak Nasional, berikut ini skenario sederhana yang direncanakan untuk diimplementasikan baik di BPTU-HPT, Sentra Peternakan Rakyat, maupun Peternak Peternakan komersil lainnya :

\section{Pencatatan data awal}

\section{Petugas pencatat (sensus) dibekali RFID Tag dan RFID Scanner}

Contoh Format RFID Tag : 360640300000001 (format lengkap : A 0000000360 640300000001)

: Kode negara Indonesia (standar ICAR / International Committee for Animal Recording)

64 : Kode provinsi Kalimantan Timur (standar BPS / Depdagri)

03 : Kode kabupaten Berau (standar Depdagri)

$00000001 \quad$ : Nomor urut sapi

Untuk memudahkan operasional dilapangan, nomor RFID Tag juga akan tercetak pada RFID Tag. Kode penomoran individu ternak dapat dilakukan dengan jumlah digit maksimal 8 digit yang artinya dalam satu kabupaten sanggup merekam data hingga populasi ternak mencapai 99.999.999 ekor ternak dan masih memungkinkan untuk ditingkatkan hingga ke tingkat kecamatan dan desa sehingga nomenklatur pencatatan identitas digital ternak dapat semakin spesifik. 


\section{Proses pendataan sapi}

1. Apabila pada sapi sudah terdapat RFID Tag, maka petugas tinggal melakukan pembacaan menggunakan RFID Scanner (khususnya untuk sapi import).

2. Apabila pada sapi belum terdapat RFID Tag maka setelah petugas memasang RFID Tag kemudian melakukan pencatatan menggunakan RFID Scanner.

Pencatatan menggunakan RFID Scanner sekaligus mengelompokan sapi berdasarkan:

1. Jantan : Pedet, Bull, dan Steer

2. Betina : Pedet, Heifer, Heifer Bunting, Cow, Cow Bunting, dan Cow Laktasi

Setelah tugas dilapangan selesai, data dari RFID Scanner akan di download kedalam database SITN, baik melalui bluetooth maupun komunikasi serial RS-232, dan SITN secara otomatis melakukan sinkronisasi sekaligus memastikan tidak ada data individu sapi yang tercatat ganda.

\section{Update data kejadian dan tindakan}

1. Untuk setiap kejadian dan tindakan terutama yang berhubungan dengan kesehatan hewan dan aktifitas reproduksi, petugas yang berwenang melakukan update data kedalam SITN.

2. Update data dapat dilakukan melalui Aplikasi SITN yang tersebar disetiap kantor dinas, website SITN, atau Aplikasi Mobile SITN, dengan menggunakan RFID Tag sebagai identitas sapi.

\section{Perpindahan sapi}

1. Tujuan keluar sapi dibagi menjadi 2.

2. Ke RPH untuk kemudian dipotong.

3. Ke tempat lain untuk tetap dipelihara.

4. Setiap sapi yang keluar dari Farm (origin) untuk diberangkatkan baik ke farm lain maupun RPH (destination) dilakukan pencatatan RFID Tag.

5. Baik untuk perpindahan antar kota / kabupaten maupun antar provinsi, perjalanan sapi akan melalui "pos pantau" yang selain berfungsi untuk memeriksa jumlah, origin, dan destination, juga melakukan pembacaan RFID Tag pada setiap sapi menggunakan RFID Scanner.

6. Data dari RFID Scanner kemudian akan di download kedalam database SITN, dan sistem akan mencatat data perpindahan tersebut (untuk selanjutnya dikonfirmasi oleh pihak penerima).

7. Setelah tiba di tujuan, pihak penerima melakukan pencatatan RFID Tag yang sekaligus sebagai konfirmasi atas data perpindahan sapi yang sebelumnya tercatat pada SITN. Hal ini juga dilakukan untuk memastikan bahwa sapi-sapi yang diterima sesuai dengan pengiriman dari origin.

8. Khusus untuk tujuan ke RPH, selain pada saat penerimaan, pencatatan RFID Tag juga dilakukan sebelum sapi-sapi tersebut dipotong, yang kemudian akan merubah status pada database SITN sehingga data populasi pada SITN selalu up-to-date. 


\section{Output informasi}

Dengan 3 (tiga) langkah sederhana diatas, diperoleh banyak informasi yang bermanfaat baik untuk peternak maupun pemerintah, dimana peternak bisa melihat data riwayat penyakit/status reproduksi dari sapi-sapi yang dimilikinya, kemudian pemerintah memiliki informasi yang menggambarkan secara real peta kekuatan dan potensi yang dapat digunakan untuk pengambilan keputusan. Sistem ini diharapkan mampu memberikan informasi yang lengkap bagi peternakan komersial maupun peternakan rakyat. Tabel 1 menunjukkan detail lingkup dan fitur yang dapat disajikan pada software.

Tabel 1. Detail lingkup dan fitur yang dapat disajikan pada software

\begin{tabular}{|c|c|}
\hline Lingkup dan fitur & Data yang dapat disajikan \\
\hline Data awal & $\begin{array}{l}\text { data breed dan sex sapi } \\
\text { data bcs, class, dan status } \\
\text { data kandang/pen, paddock, dan blok } \\
\text { data kelompok dan koloni } \\
\text { data bahan baku pakan } \\
\text { data feed additive } \\
\text { data konsentrat dan hijauan } \\
\text { data semen beku } \\
\text { data petugas breeding } \\
\text { data vitamin dan obat } \\
\text { data diagnosa penyakit } \\
\text { kondisi hasil treatment } \\
\text { data customer dan suplier }\end{array}$ \\
\hline Aktifitas persediaan & $\begin{array}{l}\text { permintaan pengadaan barang } \\
\text { pemesanan, penerimaan, dan retur barang } \\
\text { pengeluaran /pemakaian } \\
\text { produksi konsentrat } \\
\text { pengeluaran dan penjualan konsentrat } \\
\text { penyesuaian persediaan }\end{array}$ \\
\hline Aktifitas fattening & $\begin{array}{l}\text { data shipment } \\
\text { timbang awal } \\
\text { pemberian pakan } \\
\text { treatment } \\
\text { mutasi individu dan koloni } \\
\text { timbang ulang (reweight) } \\
\text { penjualan sapi: reguler, reject, dan potong paksa } \\
\text { administrasi penjualan: slip, surat jalan, dan faktur } \\
\text { pencatatan sapi mati }\end{array}$ \\
\hline
\end{tabular}


Lanjutan Tabel 1. Detail lingkup dan fitur yang dapat disajikan pada software

\begin{tabular}{|c|c|}
\hline & penggantian ear tag \\
\hline \multirow[t]{22}{*}{ Aktifitas breeding } & data shipment \\
\hline & timbang awal \\
\hline & setup populasi kelompok \\
\hline & maping data koloni \\
\hline & update bcs koloni \\
\hline & pemberian pakan \\
\hline & treatment \\
\hline & mutasi individu dan koloni \\
\hline & timbang ulang (reweight) \\
\hline & pemeriksaan organ reproduksi \\
\hline & penerimaan semen beku \\
\hline & sinkronisasi oestrus \\
\hline & pelaksanaan ib \\
\hline & pemeriksaan kebuntingan \\
\hline & sapi melahirkan \\
\hline & identifikasi hasil breeding \\
\hline & timbang awal weaner \\
\hline & $\begin{array}{l}\text { penjualan sapi: reguler, non produktif, reject, dan } \\
\text { emergency slaughter }\end{array}$ \\
\hline & administrasi penjualan: slip, surat jalan, dan faktur \\
\hline & pencatatan sapi mati \\
\hline & update jenis (breed, class, status, bcs individu) \\
\hline & penggantian ear tag \\
\hline \multirow[t]{4}{*}{ Laporan persediaan } & daftar transaksi sesuai aktifitas persediaan \\
\hline & rencana kedatangan barang \\
\hline & kartu stok dan mutasi persediaan \\
\hline & analisa kecukupan stok \\
\hline \multirow[t]{9}{*}{ Laporan fattening } & daftar transaksi sesuai aktifitas fattening \\
\hline & populasi per kandang \\
\hline & $\begin{array}{l}\text { estimasi populasi berdasarkan lama perihara dan } \\
\text { proyeksi berat }\end{array}$ \\
\hline & summary populasi \\
\hline & riwayat pemberian pakan \\
\hline & riwayat pengobatan sapi \\
\hline & produktifitas pemeliharaan (adg) \\
\hline & summary penjualan \\
\hline & produktifitas penjualan (adg) \\
\hline
\end{tabular}


Lanjutan Tabel 1. Detail lingkup dan fitur yang dapat disajikan pada software

\begin{tabular}{ll}
\hline Laporan breeding & daftar transaksi sesuai aktifitas breeding \\
& populasi per kelompok koloni \\
& summary populasi \\
& riwayat pemberian pakan \\
& riwayat pengobatan sapi \\
& conception rate, calving rate, dan weaning rate \\
& estimasi kelahiran dan jarak kelahiran \\
& estimasi penyapihan dan usia penyapihan \\
& produktifitas weaner (adg) \\
& mortalitas \\
& summary penjualan \\
\hline
\end{tabular}

\section{KESIMPULAN}

Model pencatatan digital menggunakan RFID dapat diimplementasikan pada peternakan nasional dengan berbagai skenario tipologi baik secara makro nasional maupun regional pada perusahaan peternakan, kawasan peternakan maupun sentra peternakan rakyat. Skenario sederhana yang direncanakan untuk diimplementasikan baik di BPTU-HPT, Sentra Peternakan Rakyat, maupun Peternak Peternakan komersil lainnya adalah pencatatan data awal, update data kejadian dan tindakan, serta pencatatan perpindahan ternak. Output informasi yang dapat disajikan dengan menggunakan software yang dikembangkan adalah data awal, aktivitas persediaan, aktivitas fattening, aktivitas breeding, laporan persediaan, laporan fattening, laporan breeding.

\section{DAFTAR PUSTAKA}

Adrion F, Kapun A, Holland EM, Staiger M, Löb P, Gallmann E. 2017. Novel approach to determine the influence of pig and cattle ears on the performance of passive UHF-RFID ear tags. Comp Electr Agric. 140:168-179.

Adrion F. 2018. Adaption and assessment of a UHF-RFID system for livestock management [Disertation]. [Stuttgart (Germany)]: University of Hohenheim.

Feng J, Fu Z, Wang Z, Xu M, Zhang X. 2013. Development and evaluation on a RFID-based traceability system for cattle/beef quality safety in China. J Food Control. 31:314-325.

Foster TP, Schweihofer JP, Grooms DL, Clarke RH, Buskirk DD. 2018. Comparison of beef traceability in serial and parallel fabrication systems using RFID and two-dimensional barcodes. J Transl Anim Sci. 2:101-110.

Hammer N, Adrion F, Staiger M, Holland E, Gallmann E, Jungbluth T. 2016. Comparison of different ultra-high-frequency transponder ear tags for simultaneous detection of cattle and pigs. J Livest Sci. 187:125-137.

Hong-da W. 2012. Application of radio frequency identification (RFID) in dairy information management. J Northeast Agricultural University. 19:78-81. 
Liang W, Cao J, Fan Y, Zhu K, Dai Q. 2015. Modeling and implementation of cattle/beef supply chain traceability using a distributed RFID-based framework in China. J Plos One. 2:1-17.

Myerson JM. 2007. RFID in the supply chain: a guide to selection and implementation. New York (USA): Auerbach Publications.

Roberts AJ, Wallace LE, Harbac M, Paterson JA. 2012. Case study: Retention and readability of radio frequency identification transponders in beef cows over a 5-year period. $\mathbf{J}$ Professional Anim Scientist. 28:221-226.

Wibowo MC, Wahyuni PW, Mardiana IDGR, Rasmana ST. 2013. Sistem informasi dan registrasi ternak pada kelompok peternak kambing di Malang. Prosiding Seminar Nasional Teknologi Informasi dan Multimedia. Yogyakarta (Indonesia): STMIK AMIKOM. hlm. 19-26.

Williams LR, Fox DR, Hurley GJB, Swain DL. 2019. Use of radio frequency identification (RFID) technology to record grazing beef cattle water point use. J Comp Electr Agric. 156:193-202.

Wallace LE, Paterson JA, Clark R, Harbac M, Kellom A. 2008. Readibility of thirteen different radio frequency identification ear tags by three different multi-panel reader systems for use in beef cattle. J Professional Anim Scientist. 24:384-391. 